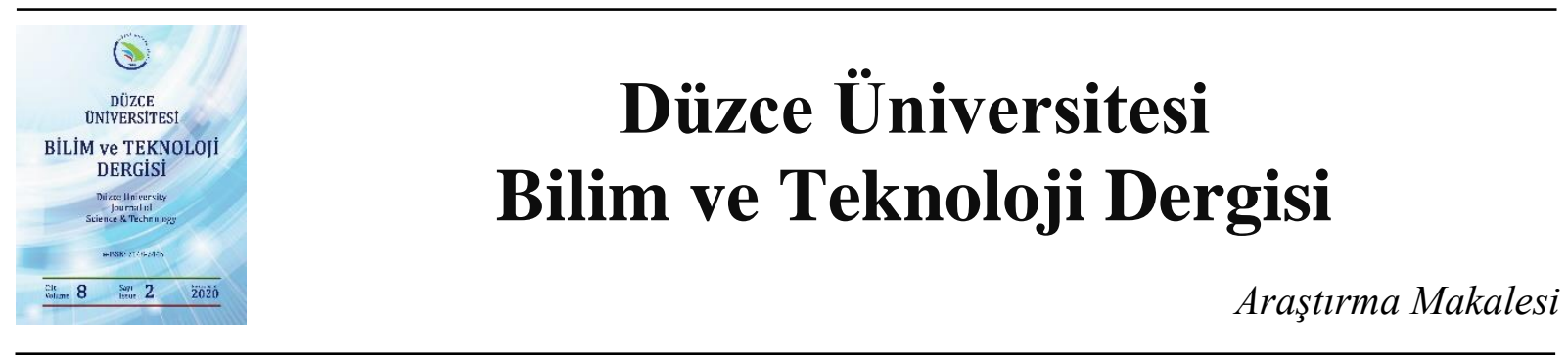

\section{Orman Ürünleri Sanayisinde Örgütsel Çatışma Yönetimi (Bolu, Düzce ve Bartın İlleri Örneği)}

\author{
(iD Tarık GEDIK ${ }^{a, *}$, (D) Şeyma ÇET ${ }^{\mathrm{b}}$ \\ ${ }^{a}$ Orman Endüstri Mühendisliği Bölümü, Orman Fakültesi, Düzce Üniversitesi, Düzce, TÜRKIYYE \\ ${ }^{b}$ Orman Endüstri Mühendisliği ABD, Fen Bilimleri Enstitüsü, Düzce Üniversitesi, Düzce, TÜRKIYE \\ * Sorumlu yazarin e-posta adresi: tarikgedik@duzce.edu.tr
}

DOI : 10.29130/dubited.681609

\begin{abstract}
ÖZET
Hem iş hayatında hem de sosyal hayatta varlığını önemli derecede hissettiğimiz bir kavram olarak tanımlanan çatışma, özellikle örgütlerde üzerinde durulması ve irdelenmesi gereken bir konudur. Çalışma kapsamında Bolu, Düzce ve Bartın illerinde faaliyette bulunan orman ürünleri sanayi işletmelerinde çalışanların örgütsel çatışmanın yönetilmesinde kullandıkları stratejiler araştıılmaya çalışılmıştır. Araştırma kapsamında toplam değerlendirilebilir 280 anket üzerinden istatistiksel değerlendirmeler yapılmıştır. Çalışma kapsamında veri elde etmek için 2 kısım, 8 farklı soru ve 28 yargıdan oluşan anket formundan yararlanılmıştır. Çalışma sonucunda katılımcıların çatışma çözme stratejilerinden bütünleş(tir)me stratejini en yüksek oranda kullandıkları, kaçınma stratejisini de en az oranda kullandıkları belirlenmiştir. Erkeklerin çatışma çözme stratejilerinden hükmetme stratejisini kadınlardan daha fazla kullandıkları belirlenmiş̧ir.
\end{abstract}

Anahtar Kelimeler: Örgütsel çatışma yönetimi, Orman ürünleri sanayi, Bolu, Düzce, Bartın

\section{Organizational Conflict Management Strategies in Forest Products Industry (The Case of Bolu, Düzce and Bartın Provinces)}

\begin{abstract}
Conflict, defined as a concept in which we feel its existence in both business and social life, is an issue that needs to be emphasized and examined in organizations. In this study, the organizational conflict management strategies used by the employees working in forest products industrial enterprises in Bolu, Düzce and Bartın provinces were investigated. Statistical evaluations were made on 280 evaluable questionnaires. In order to obtain data, a questionnaire consisting of 2 sections, 8 different questions and 28 judgments was used. As a result of the study, it was determined that the participants used the integration strategy from conflict resolution strategies at the highest rate and they used the avoidance strategy at the lowest rate. It was determined that men use the organizational conflict management strategy of dominating conflict resolution strategies more than women.
\end{abstract}

Keywords: Organizational conflict management, Forest product industry, Bolu, Duzce, Bartın

Geliş: 29/01/2020, Düzeltme: 20/04/2020, Kabul: 28/04/2020 


\section{GIRIS}

Çalışma hayatında herkesin bir şekilde karşılaştığı olgu olan çatışma, tüm toplumlarda görülmüş; bireyler, gruplar, örgütler, hatta uluslar içinde veya arasında ortaya çıkmış sosyal bir olgudur [1].

Organizasyonlarda meydana gelen çatışmalar, yöneticilerin en fazla uğraştıkları, zamanlarının önemli bir bölümünü ayırdıkları konulardan biridir. Organizasyonlar içerisinde farklı çalışma alışkanlıklarına sahip iş görenlerin bir araya gelerek gerçekleştirdiği faaliyetler organizasyonlarda birçok alanda başarıyı beraberinde getirdiği gibi, birçok sorunların da ortaya çıkmasına neden olmuştur [2].

Her ne kadar örgütlerde çatışma istenmeyen bir durum olarak gözükse de, örgütlere dinamizm katması ve yeni fikirlerin oluşmasına katkı sağlaması açısından varlığ kabullenilmiş, olumlu bir biçimde yönetilmesi için çözümler aranmaya başlanmıştır. Çatışmanın olmadığı örgütler, durağan bir yapıya bürünmekte, gelişmeyi sağlayacak iç dinamizmden yoksun kalmaktadırlar. Bu nedenle de ortaya "çatışma yönetimi” kavramı çıkmaktadır [2].

\section{GENEL BILLGILER}

\section{A. ÇATIŞMA KAVRAMI}

Çatışma, gerek iş alanında gerekse de sosyal hayatta varlığı önemli derecede hissedilen bir kavramdır. Çatışma hem aile hem de arkadaşlarımızla olan ilişkilerimizde kendini gösterebildiği gibi, iş arkadaşlarımızla olan çalışmalarımızda, yöneticiler ve astlar arasındaki ilişkiler de dahil olmak üzere her alanda karşımıza çıkmaktadır. Kısaca insanın olduğu her ortamda çatışma kavramına rastlamak mümkündür [2]. Aslında çatışma, bireyler ve gruplar arasında amaç, tercih, ilgi alanı, değer yargısı ve algısı gibi konuların farklılıklarından ötürü meydana gelen bir durumdur [3].

Kişiler arasında ortaya çıkan çatışmaların gözlemlenmesinde çalışanların moral bozukluklarının olması, birbirleri ile iletişim kurmada isteksiz olmaları, verimliliklerinde sürekli olarak düşmelerin gözlenmesi, çatışmaya neden olacak bir durum olamamasına rağmen çalışanların kızgın olmaları, rahatsız olunmamasına rağmen rapor alınması ve rapor oranlarında artışlar yaşanması, iş kazalarında ve hatalı ürün üretiminde artışlar görülmesi, çalışanlar arasında görüş farklılıkları ve buna bağlı olarak seslerin yükselmesi, bireylerin iletişim halinde oldukları kişilerin fikirlerini yok saymaları gibi durumlar gözlemlenilebilir [4].

\section{B. ÖRGÜTSELÇATIŞMA KAVRAMI}

Örgütlerde araştırılması ve üzerinde durulması gereken bir olgu olan örgütsel çatışma durumunda örgütlerde yöneticilerin ortaya çıkan çatışmaya bir çözüm yolu bulmaya çalışmak için işe ayırdıkları zamanlarından çok daha fazla zamanı, bu çatışmaları çözmek için harcamaktadırlar. Bu nedenle çatışma kavramı, örgütsel yaşam, performans/verimlilik ve örgüt kültürü üzerinde önemli bir etkiye sahiptir [2]. Eğer örgütlerde sürekli olarak çatışmalar yaşanıyorsa, o örgütlerde örgütlerin yenilikçi olması, yaratıcı fikirler ortaya koyması, performans ve verimlilikte artışların gerçekleşmesi beklenmemelidir. Çatışmaların örgütlerde olumlu sonuçlarının da olduğu literatürde yer almaktadır.

\section{C. ÖRGÜTSEL ÇATIŞMA YÖNETIMI VE ÇATIŞMA ÇÖZME YÖNTEMLERİ}

Çatışmalar, aslında çatışma yaşanan olgu/birey ile yüzleşilmesi gereken doğal bir durumdur. Bu nedenle ortaya çıkan çatışmalarda çatışma çözme davranışları önemli bir yere sahiptir ve bireylerin düştükleri anlaşmazlıklarda çatışma çözme davranışını, çatışma anında bireylerin izledikleri yöntemler belirlemektedir. $\mathrm{Bu}$ nedenle çatışmanın çözümünde çalışanların çatışma çözmeye ilişkin değerleri, tutumları ve yargıları önemli bir rol oynamaktadır [5]. 
Çatışma yönetimi konusunda literatürde çok faza yaklaşım bulunsa da Rahim modeli en çok kullanılan çatışma çözme stratejilerinden biridir. Çoğu literatür çalışmasında Rahim ölçeğinden yararlanılarak oluşturulmuş Rahim örgütsel çatışma çözüm yolları kullanılmaktadır. Bu çatışma çözme stratejisinde, bireyin kendisi için ve başkaları için endişelenme düzeyleri iki boyutta irdelenmekte ve beş çatışma çözme stratejisinden oluşmaktadır. Bu beş çatışma yöntem stratejisi [6];

Bütünleştirme: Bireyin kendisi ve karşı taraf için endişelendiği durumlarda kullandığı yöntemdir. Etkin bir çözüme ulaşmak için iki tarafın da kabul ettiği karşılıklı fikir alışverişi, açıklık, bilgi paylaşımı ve farklılıkları dikkate alan bir yöntemdir. Bu yöntemde problem çözmeye ve kazan-kazan yaklaşımına dayanan iş birliği yöntemi söz konusudur. Çatışma yönetimi konusunda bu yöntemi kullanan birey, kendisi ve başkalarının ihtiyaçları doğrultusunda problemlere çözüm yolları üretmeye çalışır [6].

Ödün Verme (Uyma): Birey bu yöntemde kendisinden daha çok karşı taraf için endişelenmektedir. Karşı tarafın endişelerini gidermek adına farklılıklar göz ardı edildiği ve ortak yönlerin vurgulanmasına odaklı bir yöntemdir. Burada taraflardan biri kendi ihtiyaçlarını yok saymaktadır [6]. Bir başka ifadeyle uyumlu tarzdaki kişi, karşı tarafin isteklerini yerine getirme ve gönlünü alma davranışıyla çatışmayı çözüme ulaştırmaktadır [7].

Hükmetme: Bireyin karşı taraftan daha çok kendisine yöneldiği ve kendisi için endişelendiği durumlarda kullandığ 1 bir yöntemdir. Burada kazan-kaybet yaklaşımı söz konusudur ya da birey kazanmak için gücünü kullanmaktadır [6]. Hükmetme yönteminde kişisel çıkarlar ön planda tutulurken, iş birliği yapılmamakta ve yıkıcı etkinin hakim olduğu gözlemlenmektedir [8].

Kaçınma: Birey hem kendisi için hem de karşı taraf için en düşük düzeyde endişelendiğinde bu yöntemi kullanmaktadır. Kaçınma yönteminde iş birliği yoktur ve kayıtsız kalma ve çatışmaya girmeden geri çekilme söz konusudur. Çatışma konularının görmezden gelindiği, çatışmanın bastırıldığı ve bir tarafa bırakma yaklaşımı görülen bir yöntemdir. Bu yöntemde hem birey hem de diğer taraf amaçlarına ulaşamadığından tatmin olamazlar [6]. Her iki tarafin da kaybetme durumu yaşamasından dolayı kaybet-kaybet yaklaşımı olarak da ifade edilen bir yöntemdir. $\mathrm{Bu}$ yöntemde görmezden gelinen sorunlar çözüme ulaşamadıkları için, zaman içinde çatışmalar daha yıkıcı hale dönüşebilirler [8].

Uzlaşma: Birey kendisi ve karşı taraf için orta düzeyde endişelendiği durumlarda kullandığı yöntemdir. Çatışma çözümünde en sık başvurulan yöntem olan uzlaşma, karşılıklı fedakarlık ile her iki taraf için kabul edilebilir bir karara ulaşmak için kullanılır. Bu yöntemde kazanan ya da kaybeden yoktur, tarafların kendilerince kazanım sağlaması için çaba gösterilmektedir [6].

\section{MATERYAL VE YÖNTEM}

\section{A. MATERYAL}

Bolu, Düzce ve Bartın ilerinde faaliyette bulunan orman ürünleri sanayi işletmelerinde çalışanların örgütsel çatışmaların yönetilmesinde hangi yöntemleri ağırlıklı olarak kullandıklarının analiz edildiği bu çalışmada evren; illerin Ticaret ve Sanayi Odalarına kayıtlı bulunan ve 10 ve daha fazla çalışanı olan 173 farklı işletme ile 4345 çalışandan oluşmaktadır [9-11], (Tablo 1).

Tablo 1. Çalışma evreni

\begin{tabular}{lcccc}
\hline İl & $\begin{array}{c}\text { İşletme } \\
\text { sayısı }\end{array}$ & $\begin{array}{c}\text { Çalışan } \\
\text { sayısı }\end{array}$ & $\begin{array}{c}\text { Ulaşılması gereken } \\
\text { anket sayısı }\end{array}$ & Ulaşılan anket sayısı \\
\hline Bolu & 88 & 1174 & 69 & 75 \\
Düzce & 66 & 2838 & 167 & 168 \\
Bartın & 19 & 333 & 19 & 37 \\
Toplam & $\mathbf{1 7 3}$ & $\mathbf{4 3 4 5}$ & $\mathbf{2 5 5}$ & $\mathbf{2 8 0}$ \\
\hline
\end{tabular}


Çalışma kapsamında çalışma evrenini istatistiki olarak temsil edecek örnekleme ulaşmak için uygulanacak anket sayısı hesaplanırken $\% 90$ güven düzeyi ve $\% 5$ örnekleme hatası ile ulaşılması gereken minimum örneklem 255 olarak hesaplanmıştır [12]. Çalışma kapsamında da toplam değerlendirilebilir 280 anket üzerinden istatistiksel değerlendirmeler yapılmıştır (Tablo 1). Çalışmada anket uygulaması Eylül-Kasım 2013 döneminde evren içerisinde yer alan çalışanlarla yüz yüze görüşme (anket uygulama) yapılarak gerçekleştirilmiştir.

\section{B. YÖNTEM}

Çalışmada veri elde etme aracı olarak çalışma amacına uygun olacak şekilde geliştirilen anketten yararlanılmıştır [13-17]. Geliştirilen anket formu 2 kısım, 8 farklı soru ve 28 yargıdan oluşturulmuştur. Anket formunun birinci kısımda katılımcıların bazı demografik özellikleri sorgulanmıştır. Anketin ikinci kısmında Özgan tarafından Türkçeye uyarlanmış Rahim Örgütsel Çatışma Ölçeğinden yararlanılarak örgütsel çatışma konusu ölçülmeye çalışılmıştır [14]. Sorgulamalarda ilgili yargılara katılım derecelerinin değerlendirilmesinde 5'li Likert ölçeğinden (1:Hiç katılmıyorum, 2: Katılmıyorum, 3: Kararsızım 4: Katılıyorum, 5: Tümüyle katılıyorum) yararlanılmıştır.

Belirlenen çalışma amacına uygun olarak çatışma çözme stratejilerinin demografik özelliklere göre farklılıkları parametrik hipotez testlerinin varsayımlarının karşılandığı durumlarda iki gruplu örnekler için bağımsız t testi, üç ve daha fazla olan gruplar için tek yönlü varyans analizi (ANOVA) testleri kullanılmıştır. Verilerde parametrik hipotez testlerinin varsayımlarının karşılanmadı̆̆ 1 durumlarda veriler için parametrik olmayan istatistik tekniklerinden de yararlanılmıştır. Bu amaçla ele alınan parametrik olmayan hipotez testleri Mann-Whitney U testi ve Kruskal-Wallis siralamalı tek yönlü varyans analizidir. Sonuçlar \%95'lik güven aralığında, anlamlılık $\mathrm{p}<0,05$ düzeyinde değerlendirilmiştir.

Araştırma kapsamında kullanılan ölçeğin güvenilirliği Cronbach Alpha katsayısı, geçerliliği de örnekleme yeterlilik ölçüsüne bakılarak (KMO) hesaplanmıştır. Hesaplamalar sonucunda elde edilen sonuçlara göre kullanılan ölçeğin geçerlilik analizi sonucu KMO değeri 0,799; Barlett küresellik değeri 2490,911 ve güvenilirlik analizi sonuçlarının da 0,506 ile 0,859 arasında değiştiği görülmektedir (Tablo 2). Elde edilen bu sonuçlar dikkate alındığında kullanılan ölçeğin geçerlilik ve güvenilirlik açısından bir sorun teşkil etmediği belirlenmiştir [18, 19].

Tablo 2. Geçerlilik ve güvenilirlik analizi sonuçları

\begin{tabular}{lcc}
\hline \multicolumn{1}{c}{ Alt boyutlar } & Güvenilirlik & Geçerlilik \\
\hline Bütünleşme & 0,767 & \\
Ödün verme & 0,656 & \\
Hükmetme & 0,669 & 0,799 \\
Kaçınma & 0,506 & \\
Uzlaşma & 0,562 & \\
Çatışma çözme toplam & $\mathbf{0 , 8 5 9}$ & \\
\hline
\end{tabular}

\section{BULGULAR}

Çalışmaya \%90,4 oranında erkek çalışanların, \%66,7 oranında evli çalışanların katıldıkları belirlenmiştir. Katılımcıların \%59,6'sı işçi konumunda çalışırken, \%10 oranında operatör, \%9,6 oranında şef/amir, $\% 7,1$ oranında yönetici, $\% 6,8$ oranında usta ve büro elemanı olarak işletmelerinde istihdam edildikleri belirlenmiştir.

Katılımcıların 19-59 yaş aralığında olduğu, ortalama yaşın da 33,8 olduğu hesaplanmıştır. Katılımcılar ağırlıklı olarak (\%50,7) 26-35 yaş aralığında olduğu, \%26,8 oranında 36-45 yaş aralı̆̆ında, \%12,9 oranında 25 ve daha düşük yaşta ve $\% 9,6$ oranında da 46 ve daha büyük yaşta oldukları belirlenmiştir. 
Katılımcıların ağırlıklı olarak $(\% 45,4)$ lise eğitim seviyesine sahip olduğu belirlenirken, \%17,9 oranında ilkokul, \%16,1 oranında ortaokul, \%13,9 oranında lisans ve $\% 6,8$ oranında da ön lisans mezunu oldukları belirlenmiştir.

Katılımcıların mesleki deneyimleri incelendiğinde 1-45 yıl arasında çalışanların olduğu örneklemde 5 yıl ve daha az çalışma süresine sahip olanlar \%36,8 oranında iken, 21 yıl ve daha fazla çalışma süresine sahip olanların \%13,2 ile en düşük orana sahip oldukları belirlenmiştir. Katılımcıların aynı işletmede çalışma süreleri irdelendiğinde de 1-39 yıl arasında çalışma süresine sahip katılımcılar bulunurken, 5 yıl ve daha az çalışma süresine sahip olanların oranı $\% 65,7$ iken, çalışma yılı arttıkça bu oranın azaldığı gözlenmiştir.

Rahim örgütsel çatışma yönetim modelinde, çatışma taraflarının kendisine ve karşı taraflara ilgisi çerçevesinde şekillendirdiği bütünleş(tir)me (işbirliği), hükmetme, uzlaş(tır)ma, ödün verme (taviz) ve kaçınmadan oluşan beş adet çatışma yönetim stratejisine yer vermiştir [20, 21]. Bolu, Düzce ve Bartın ilerinde faaliyette bulunan orman ürünleri sanayi işletmelerinde çalışanların örgütsel çatışmaların yönetilmesinde kullandıkları çatışma yönetim stratejilerine ait katılma dereceleri Tablo 3'de gösterilmiştir.

Tablo 3. Katılımcıların kendi algılarına göre çatışma yönetim stratejisi tercihleri

\begin{tabular}{llllccccc}
\hline $\begin{array}{l}\text { Çatışma } \\
\text { yönetim } \\
\text { stili }\end{array}$ & $\mathbf{n}$ & $\mathbf{X}$ & $\mathbf{S S}$ & Bütünleşme & $\begin{array}{c}\text { Ödün } \\
\text { verme }\end{array}$ & Hükmetme & Kaçınma & Uzlaşma \\
\hline $\begin{array}{l}\text { Bütünleşme } \\
\text { Ödün }\end{array}$ & 276 & 4,20 & 0,542 & 1 & & & & \\
verme & 276 & 3,63 & 0,654 & $0,460^{* *}$ & 1 & & & \\
Hükmetme & 275 & 3,60 & 0,760 & $0,384^{* *}$ & $0,454^{* *}$ & 1 & & \\
Kaçınma & 276 & 3,52 & 0,647 & $0,305^{* *}$ & $0,580^{* *}$ & $0,388^{* *}$ & 1 & \\
Uzlaşma & 275 & 4,02 & 0,619 & $0,674^{* *}$ & $0,534^{* *}$ & $0,446^{* *}$ & $0,336^{* *}$ & 1 \\
$\begin{array}{l}\text { Çatışma } \\
\text { çözme top. }\end{array}$ & 276 & 3,79 & 0,481 & $0,742^{* *}$ & $0,822^{* *}$ & $0,726^{* *}$ & $0,699^{* *}$ & $0,750^{* *}$ \\
\hline
\end{tabular}

"* $<0,01$; Likert ölçek: 1 Hiç katılmıyorum, 3 Kararsızım, 5 Tümüyle katılıyorum

Çalışma sonucunda katılımcıların çatışma yönetim stratejilerinden bütünleş(tir)me stratejini en yüksek oranda kullandıkları, kaçınma stratejisini de en az oranda kullandıkları belirlenmiştir. Örgütsel çatışma ve örgütsel çatışma yönetim stratejileri arasında yüksek oranda korelasyonlar tespit edilmiştir. Çatışma çözme stratejileri arasında yapılan korelasyon analizi sonuçlarına göre her bir stratejinin birbirleri ile bir korelasyona sahip olduğu belirlenmiştir (Tablo 3). Çatışma çözme stratejilerinden uzlaşma yöntemi ile çatışmayı çözmek isteyen katılımcılar r:0,674 oranında çatışma çözme stratejisi olarak bütünleş(tir)me stratejini de uygulamaktadırlar. Literatürde yapılan çalışmalarda da katılımcıların çatışma çözme stratejilerinden bütünleş(tir)me stratejini en yüksek oranda kullandıklarını belirten çalışmalar yer almaktadır [17, 22-27]. Literatürde çatışma çözme stratejilerinden en az kullanılan stratejinin kaçınma olduğuna dair çalışmalar da yer almaktadır [22, 27]. Yıldızoğlu ve Burgaz tarafından yapılan ve okul yöneticilerinin çatışma çözme stratejilerinin irdelendiği çalışmada en az kullanılan çatışma çözme stratejisi hükmetme olarak belirlenmiştir [24].

Katılımcıların cinsiyetleri ile örgütsel çatışma yönetim stratejileri karşılaştırması Tablo 4'de gösterilmiştir. Bolu, Düzce ve Bartın illerinde faaliyette bulunan orman ürünleri sanayi işletmelerinde çalışanların cinsiyetleri ile çatışma yönetim stratejileri arasında yapılan istatistiki analizler sonucunda hükmetme çatışma çözme yönetim strateji açısından bir farklılık tespit edilirken $(p<0,05)$, diğer çatışma çözme yönetim stratejileri arasında anlamlı bir farklılık bulunamamıştır $(p>0,05)$. Erkeklerin çatışma çözme yönetim stratejilerinden hükmetmeyi daha fazla kullandıkları söylenilebilir. Öztaş ve Akın tarafından Antalya serbest ticaret bölgesinde yapılan çalı̧̧mada cinsiyet açısından çatışma çözme stratejilerinde istatistiksel olarak bir farklılık tespit edilememiştir [22]. Ayan tarafından yapılan çalışmada çatışma çözme stratejilerinden sadece kaçınma stratejisinin cinsiyete göre farklılık 
gösterdiği görülmüştür [17]. İmamoğlu ve Öztaş tarafindan yapılan çalışmalarda da çatışma çözme stratejilerinin cinsiyete göre farklılık göstermediği belirlenmiştir [28, 29].

Tablo 4. Çatışma çözme yönetim stratejilerinin cinsiyet faktörü açısından karşılaştırılması （1 Hiç katılmıyorum, 3 Kararsızım, 5 Tümüyle katılıyorum)

\begin{tabular}{|c|c|c|c|c|c|c|}
\hline & Cinsiyet & $\mathbf{n}$ & $\mathbf{X}$ & SS & $\mathbf{t}$ & $\mathbf{P}$ \\
\hline \multirow{2}{*}{ Bütünleşme } & Kadın & 26 & 4,26 & 0,506 & \multirow{2}{*}{0,643} & \multirow{2}{*}{0,520} \\
\hline & Erkek & 250 & 4,19 & 0,546 & & \\
\hline \multirow{2}{*}{ Ödün verme } & Kadın & 26 & 3,66 & 0,737 & \multirow{2}{*}{0,198} & \multirow{2}{*}{0,843} \\
\hline & Erkek & 250 & 3,63 & 0,646 & & \\
\hline \multirow{2}{*}{ Hükmetme } & Kadın & 26 & 3,24 & 0,969 & \multirow{2}{*}{$-2,498$} & \multirow{2}{*}{$\mathbf{0 , 0 1 3}$} \\
\hline & Erkek & 249 & 3,63 & 0,727 & & \\
\hline \multirow{2}{*}{ Kaçınma } & Kadın & 26 & 3,67 & 0,514 & \multirow{2}{*}{1,265} & \multirow{2}{*}{0,207} \\
\hline & Erkek & 250 & 3,50 & 0,659 & & \\
\hline \multirow{2}{*}{ Uzlaşma } & Kadın & 26 & 4,06 & 0,728 & \multirow{2}{*}{0,366} & \multirow{2}{*}{0,715} \\
\hline & Erkek & 249 & 4,02 & 0,608 & & \\
\hline
\end{tabular}

Katılımcıların medeni durumları ile örgütsel çatışma yönetim stratejileri karşılaştırması Tablo 5'de gösterilmiştir. Bolu, Düzce ve Bartın illerinde faaliyette bulunan orman ürünleri sanayi işletmelerinde çalışanların medeni durumları ile çatışma yönetim stratejileri arasında yapılan istatistiki analizler sonucunda kaçınma çatışma çözme yönetim strateji açısından bir farklılık tespit edilirken ( $<<0,05)$, diğer çatışma çözme yönetim stratejileri arasında anlamlı bir farklılık bulunamamıştır ( $>0,05$ ). Medeni durumu bekâr olan katılımcıların çatışma çözme yönetim stratejilerinden kaçınma stratejisini daha fazla kullandıklanı söylenilebilir. Şahin ve Yüksel Şahin tarafından yapılan çalışmada katılımcıların medeni durumları ile çatışma çözme stratejileri arasında anlamlı farklılık bulunamamıştır [30].

Tablo 5. Çatışma çözme yönetim stratejilerinin katılımcıların medeni durumu açısından karşılaştırılması (1 Hiç katılmıyorum, 3 Kararsızım, 5 Tümüyle katıllyorum)

\begin{tabular}{|c|c|c|c|c|c|c|}
\hline & $\begin{array}{l}\text { Medeni } \\
\text { durum }\end{array}$ & $\mathbf{n}$ & $\mathbf{X}$ & SS & $\mathbf{t}$ & $\mathbf{P}$ \\
\hline \multirow{2}{*}{ Bütünleşme } & Evli & 184 & 4,21 & 0,557 & \multirow{2}{*}{0,256} & \multirow{2}{*}{0,798} \\
\hline & Bekâr & 91 & 4,19 & 0,492 & & \\
\hline \multirow{2}{*}{ Ödün verme } & Evli & 184 & 3,61 & 0,625 & \multirow{2}{*}{$-0,914$} & \multirow{2}{*}{0,362} \\
\hline & Bekâr & 91 & 3,69 & 0,699 & & \\
\hline \multirow{2}{*}{ Hükmetme } & Evli & 183 & 3,56 & 0,745 & \multirow{2}{*}{$-1,071$} & \multirow{2}{*}{0,285} \\
\hline & Bekâr & 91 & 3,67 & 0,791 & & \\
\hline \multirow{2}{*}{ Kaçınma } & Evli & 184 & 3,45 & 0,649 & \multirow{2}{*}{$-2,754$} & \multirow{2}{*}{0,006} \\
\hline & Bekâr & 91 & 3,67 & 0,622 & & \\
\hline \multirow{2}{*}{ Uzlaşma } & Evli & 183 & 3,99 & 0,640 & \multirow{2}{*}{$-1,474$} & \multirow{2}{*}{0,142} \\
\hline & Bekâr & 91 & 4,10 & 0,568 & & \\
\hline
\end{tabular}

Katılımcıların yaş gruplamaları ile örgütsel çatışma yönetim stratejileri karşılaştırması Tablo 6'da gösterilmiştir. Bolu, Düzce ve Bartın illerinde faaliyette bulunan orman ürünleri sanayi işletmelerinde çalışanların yaş gruplamaları ile çatışma yönetim stratejileri arasında yapılan istatistiki analizler sonucunda bütünleştirme çatışma çözme yönetim strateji açısından bir farklılık tespit edilirken $(\mathrm{p}<0,05)$, diğer çatışma çözme yönetim stratejileri arasında anlamlı bir farklılık bulunamamıştır (p>0,05). Yaş1 46 ve daha yükssek olan katılımcıların 45 ve daha düşük yaştakilerden daha yüksek oranda çatışma çözme yönetim stratejilerinden bütünleştirme stratejisini kullandıkları söylenilebilir. Polatlı ve Sobacı tarafından banka müdürlerine yönelik yapılan çalışmada çatışma çözme stratejilerinin yaşa göre farklılık göstermediği belirlenmiştir [31]. Ayan tarafindan yapılan çalışmada ödün verme ve hükmetme çatışma çözme stratejilerinin yaşa göre farklılık gösterdiği ve 45 ve daha yüksek yaştakilerin bu stratejileri daha fazla kullandıkları belirlenmiştir [17]. 
Tablo 6. Çatışma çözme yönetim stratejilerinin katılımcıların yaş gruplaması açısından karşılaştırılması (1 Hiç katılmıyorum, 3 Kararsızım, 5 Tümüyle katıllyorum)

\begin{tabular}{|c|c|c|c|c|c|c|c|}
\hline & Yaş grubu & $\mathbf{n}$ & $\mathbf{X}$ & SS & HG & $\mathbf{F}$ & $\mathbf{P}$ \\
\hline \multirow{4}{*}{ Bütünleşme } & 25 ve daha az & 36 & 4,19 & 0,461 & $\mathrm{a}$ & \multirow{4}{*}{2,975} & \multirow{4}{*}{$\mathbf{0 , 0 3 2}$} \\
\hline & $26-35$ aras1 & 140 & 4,13 & 0,566 & a & & \\
\hline & $36-45$ aras1 & 74 & 4,24 & 0,559 & a & & \\
\hline & 46 ve daha fazla & 26 & 4,46 & 0,373 & $\mathrm{~b}$ & & \\
\hline \multirow{4}{*}{ Ödün verme } & 25 ve daha az & 36 & 3,61 & 0,728 & $\mathrm{a}$ & \multirow{4}{*}{0,277} & \multirow{4}{*}{0,842} \\
\hline & $26-35$ aras1 & 140 & 3,62 & 0,649 & $\mathrm{a}$ & & \\
\hline & $36-45$ aras1 & 74 & 3,64 & 0,660 & $\mathrm{a}$ & & \\
\hline & 46 ve daha fazla & 26 & 3,74 & 0,571 & $\mathrm{a}$ & & \\
\hline \multirow{4}{*}{ Hükmetme } & 25 ve daha az & 36 & 3,71 & 0,690 & $\mathrm{a}$ & \multirow{4}{*}{0,343} & \multirow{4}{*}{0,794} \\
\hline & $26-35$ aras1 & 139 & 3,58 & 0,728 & $\mathrm{a}$ & & \\
\hline & $36-45$ aras 1 & 74 & 3,60 & 0,828 & $\mathrm{a}$ & & \\
\hline & 46 ve daha fazla & 26 & 3,52 & 0,843 & $\mathrm{a}$ & & \\
\hline \multirow{4}{*}{ Kaçınma } & 25 ve daha az & 36 & 3,60 & 0,609 & $\mathrm{a}$ & \multirow{4}{*}{1,552} & \multirow{4}{*}{0,201} \\
\hline & $26-35$ aras1 & 140 & 3,44 & 0,632 & $\mathrm{a}$ & & \\
\hline & $36-45$ aras1 & 74 & 3,62 & 0,665 & $\mathrm{a}$ & & \\
\hline & 46 ve daha fazla & 26 & 3,54 & 0,709 & $\mathrm{a}$ & & \\
\hline \multirow{4}{*}{ Uzlaşma } & 25 ve daha az & 36 & 3,97 & 0,598 & $\mathrm{a}$ & \multirow{4}{*}{0,615} & \multirow{4}{*}{0,606} \\
\hline & $26-35$ aras 1 & 139 & 4,03 & 0,616 & a & & \\
\hline & $36-45$ aras1 & 74 & 3,99 & 0,649 & $\mathrm{a}$ & & \\
\hline & 46 ve daha fazla & 26 & 4,16 & 0,587 & $\mathrm{a}$ & & \\
\hline
\end{tabular}

Katılımcıların eğitim düzeyleri ile örgütsel çatışma yönetim stratejileri karşılaştırması Tablo 7'de gösterilmiştir. Bolu, Düzce ve Bartın illerinde faaliyette bulunan orman ürünleri sanayi işletmelerinde çalışanların eğitim düzeyleri ile çatışma yönetim stratejileri arasında yapılan istatistiki analizler sonucunda bütünleştirme, ödün verme ve uzlaşma çatışma çözme yönetim stratejileri açısından bir farklılık tespit edilirken $(\mathrm{p}<0,05)$, hükmetme ve kaçınma çatışma çözme yönetim stratejileri arasında anlamlı bir farklılık bulunamamıştır ( $>>0,05)$. Bütünleştirme çatı̧̧ma çözme yönetim stratejisini en yüksek oranda kullananlar ilkokul mezunu katılımcilar olurken, ön lisans ve ortaokul mezunu katılımcılar en düşük oranda bu stratejiyi benimsemektedirler. Ödün verme çatışma çözme yönetim stratejisini ön lisans mezunu katılımcılar en düşük oranda kullanarak diğer eğitim düzeyinde çalışan katılımcılardan farklılaşmaktadırlar. Uzlaşma çatışma çözme stratejisini de ön lisans mezunu katılımcıların en düşük düzeyde kullandıkları belirlenmiştir. Ayan katılımcıların eğitim düzeylerine göre çatışma çözme stratejileri arasında anlamlı bir farklılık tespit edememiştir [17].

Katılımcıların çalıştıkları pozisyon ile örgütsel çatışma yönetim stratejileri karşılaştırması Tablo 8'de gösterilmiştir. Bolu, Düzce ve Bartın illerinde faaliyette bulunan orman ürünleri sanayi işletmelerinde çalışanların çalıştıkları pozisyon ile çatışma yönetim stratejileri arasında yapılan istatistiki analizler sonucunda hükmetme çatışma çözme yönetim stratejisi açısından bir farklılık tespit edilirken $(p<0,05)$, diğer çatışma çözme yönetim stratejileri arasında anlamlı bir farklılık bulunamamıştır ( $>0,05)$. Yönetici olarak çalışan katılımcıların çatışma çözme yönetim stratejisi olarak daha çok hükmetme çözüm stratejisini benimserken, işçi ve usta konumunda çalışan katılımcılar ise en az düzeyde hükmetme çatışma çözüm stratejisini benimsemektedirler. 
Tablo 7. Çatışma çözme yönetim stratejilerinin katılımcıların eğitim düzeyleri açısından karşılaştırılması (1 Hiç katılmıyorum, 3 Kararsızım, 5 Tümüyle katıllyorum)

\begin{tabular}{|c|c|c|c|c|c|c|c|}
\hline & Eğitim düzeyi & $\mathbf{n}$ & $\mathbf{X}$ & SS & HG & $\mathbf{H}$ & $\mathbf{P}$ \\
\hline \multirow{5}{*}{ Bütünleşme } & İlkokul & 48 & 4,39 & 0,531 & $\mathrm{a}$ & \multirow{5}{*}{10,433} & \multirow{5}{*}{$\mathbf{0 , 0 3 4}$} \\
\hline & Ortaokul & 44 & 4,12 & 0,567 & $\mathrm{~b}$ & & \\
\hline & Lise & 126 & 4,17 & 0,521 & $a b$ & & \\
\hline & Ön lisans & 19 & 4,02 & 0,562 & $\mathrm{~b}$ & & \\
\hline & Lisans & 39 & 4,21 & 0,547 & $a b$ & & \\
\hline \multirow{5}{*}{$\begin{array}{l}\text { Ödün } \\
\text { verme }\end{array}$} & İlkokul & 48 & 3,74 & 0,781 & $\mathrm{a}$ & \multirow{5}{*}{14,991} & \multirow{5}{*}{0,005} \\
\hline & Ortaokul & 44 & 3,78 & 0,584 & $\mathrm{a}$ & & \\
\hline & Lise & 126 & 3,63 & 0,654 & $\mathrm{a}$ & & \\
\hline & Ön lisans & 19 & 3,18 & 0,524 & b & & \\
\hline & Lisans & 39 & 3,57 & 0,523 & $\mathrm{a}$ & & \\
\hline \multirow{5}{*}{ Hükmetme } & İlkokul & 48 & 3,44 & 0,848 & $\mathrm{a}$ & \multirow{5}{*}{4,480} & \multirow{5}{*}{0,345} \\
\hline & Ortaokul & 43 & 3,54 & 0,772 & $\mathrm{a}$ & & \\
\hline & Lise & 126 & 3,69 & 0,685 & $\mathrm{a}$ & & \\
\hline & Ön lisans & 19 & 3,41 & 0,956 & $\mathrm{a}$ & & \\
\hline & Lisans & 39 & 3,65 & 0,751 & $\mathrm{a}$ & & \\
\hline \multirow{5}{*}{ Kaçınma } & İlkokul & 48 & 3,60 & 0,691 & $\mathrm{a}$ & \multirow{5}{*}{2,442} & \multirow{5}{*}{0,655} \\
\hline & Ortaokul & 44 & 3,56 & 0,731 & $\mathrm{a}$ & & \\
\hline & Lise & 126 & 3,51 & 0,607 & $\mathrm{a}$ & & \\
\hline & Ön lisans & 19 & 3,35 & 0,574 & $\mathrm{a}$ & & \\
\hline & Lisans & 39 & 3,48 & 0,667 & $\mathrm{a}$ & & \\
\hline \multirow{5}{*}{ Uzlaşma } & İlkokul & 48 & 4,14 & 0,671 & $\mathrm{a}$ & \multirow{5}{*}{10,778} & \multirow{5}{*}{0,029} \\
\hline & Ortaokul & 43 & 4,08 & 0,539 & $\mathrm{a}$ & & \\
\hline & Lise & 126 & 3,97 & 0,649 & $\mathrm{a}$ & & \\
\hline & Ön lisans & 19 & 3,66 & 0,554 & b & & \\
\hline & Lisans & 39 & 4,17 & 0,477 & a & & \\
\hline
\end{tabular}

\section{IV.SONUC}

Örgütlerde çatışma kavramı günümüzde daha sık duyduğumuz ve çalışanlar üzerindeki etkisi de yok sayılamayacak kadar önem taşıyan bir kavramdır. Çalışma kapsamında katılımcıların örgütlerinde çalışanlarla/yöneticilerle olası bir çatışma yaşanması durumunda en çok bütünleş(tir)me çatışma yönetim stratejisini benimsedikleri, kaçınma çatışma yönetim stratejisini de en az oranda kullandıkları belirlenmiştir. Örgütsel çatışma ve örgütsel çatışma yönetim stratejileri arasında yüksek oranda korelasyonlar tespit edilmiştir.

Çatışma yönetim stratejilerinden bütünleş(tir)me stratejisini benimseyen katılımcıların yüksek oranda çatışma yönetim stratejilerinden uzlaşma stratejisini de benimsemektedirler. Çalışma sonucunda erkeklerin çatışma yönetim stratejilerinden hükmetmeyi kadınlara göre daha fazla kullandıkları söylenilebilir.

Çatışmalar ile yaşamın her alanında karşılaşmak mümkündür. Bu yüzden yaşanan çatışmaların iyi yönetilmesi ve çatışma durumlarında hangi yönetim stratejisinin daha çok kullanıldığının bilinmesi örgüt yararına olacaktır. 
Tablo 8. Çatışma çözme yönetim stratejilerinin katılımcıların çalıştıkları pozisyonları açısından karşılaştırılması (1 Hiç katılmıyorum, 3 Kararsızım, 5 Tümüyle katılıyorum)

\begin{tabular}{|c|c|c|c|c|c|c|c|}
\hline & Ĕgitim düzeyi & $\mathbf{N}$ & $\mathbf{X}$ & SS & HG & $\mathbf{H}$ & $\mathbf{P}$ \\
\hline \multirow{6}{*}{ Bütünleşme } & Operatör & 28 & 4,17 & 0,610 & $\mathrm{a}$ & \multirow{6}{*}{4,527} & \multirow{6}{*}{0,476} \\
\hline & İşçi & 163 & 4,16 & 0,543 & $\mathrm{a}$ & & \\
\hline & Yönetici & 20 & 4,21 & 0,517 & $\mathrm{a}$ & & \\
\hline & Usta & 19 & 4,17 & 0,538 & a & & \\
\hline & Şef/amir & 27 & 4,33 & 0,508 & $\mathrm{a}$ & & \\
\hline & Büro elemanı & 19 & 4,37 & 0,515 & $\mathrm{a}$ & & \\
\hline \multirow{6}{*}{ Ödün verme } & Operatör & 28 & 3,38 & 0,628 & $\mathrm{a}$ & \multirow{6}{*}{8,397} & \multirow{6}{*}{0,136} \\
\hline & İşçi & 163 & 3,69 & 0,705 & $\mathrm{a}$ & & \\
\hline & Yönetici & 20 & 3,39 & 0,483 & $\mathrm{a}$ & & \\
\hline & Usta & 19 & 3,67 & 0,491 & $\mathrm{a}$ & & \\
\hline & Şef/amir & 27 & 3,68 & 0,560 & $\mathrm{a}$ & & \\
\hline & Büro elemanı & 19 & 3,68 & 0,574 & $\mathrm{a}$ & & \\
\hline \multirow{6}{*}{ Hükmetme } & Operatör & 28 & 3,76 & 0,569 & $a b$ & \multirow{6}{*}{13,066} & \multirow{6}{*}{$\mathbf{0 , 0 2 3}$} \\
\hline & İşçi & 162 & 3,50 & 0,779 & $\mathrm{a}$ & & \\
\hline & Yönetici & 20 & 4,04 & 0,638 & $\mathrm{~b}$ & & \\
\hline & Usta & 19 & 3,52 & 0,740 & $\mathrm{a}$ & & \\
\hline & Şef/amir & 27 & 3,79 & 0,741 & $a b$ & & \\
\hline & Büro elemanı & 19 & 3,47 & 0,829 & $\mathrm{a}$ & & \\
\hline \multirow{6}{*}{ Kaçınma } & Operatör & 28 & 3,23 & 0,485 & $\mathrm{a}$ & \multirow{6}{*}{9,067} & \multirow{6}{*}{0,106} \\
\hline & İşçi & 163 & 3,55 & 0,668 & $\mathrm{a}$ & & \\
\hline & Yönetici & 20 & 3,56 & 0,759 & $\mathrm{a}$ & & \\
\hline & Usta & 19 & 3,46 & 0,654 & $\mathrm{a}$ & & \\
\hline & Şef/amir & 27 & 3,59 & 0,659 & $\mathrm{a}$ & & \\
\hline & Büro elemanı & 19 & 3,56 & 0,463 & $\mathrm{a}$ & & \\
\hline \multirow{6}{*}{ Uzlaşma } & Operatör & 28 & 4,00 & 0,385 & $\mathrm{a}$ & \multirow{6}{*}{5,065} & \multirow{6}{*}{0,408} \\
\hline & İşçi & 162 & 3,98 & 0,666 & $\mathrm{a}$ & & \\
\hline & Yönetici & 20 & 3,93 & 0,618 & $\mathrm{a}$ & & \\
\hline & Usta & 19 & 4,03 & 0,640 & $\mathrm{a}$ & & \\
\hline & Şef/amir & 27 & 4,17 & 0,560 & a & & \\
\hline & Büro elemanı & 19 & 4,26 & 0,510 & $\mathrm{a}$ & & \\
\hline
\end{tabular}

TEŞEKKÜR: Bu çalışma Şeyma ÇET tarafından Düzce Üniversitesi Fen Bilimleri Enstitüsü Orman Endüstri Mühendisliği ABD’da yapılan yüksek lisans tezinden üretilmiştir.

\section{KAYNAKLAR}

[1] J.Z. Rubin, "Models of Conflict Management," Journal of Social Issues, c. 50, s. 1, ss. 33-45, 1994.

[2] K. Baykal ve A. Kovancı, "Yönetici ve Astlar Arasındaki Anlaşmazlıkların Çözümüne Yönelik Bir Araştırma," Havacılık ve Uzay Teknolojileri Dergisi, c. 3, s. 3, ss. 21-38, 2008.

[3] A.D. Akkirman, "Etkin Çatışma Yönetimi ve Müdahele Stratejileri," D.E.Ü.İ.İ.B.F. Dergisi, c. 13 , s.2, ss. 1-11, 1998.

[4] E. Karip, Çatışma Yönetimi, 2. baskı, Ankara, Türkiye: PegemA Yayınevi, 2000. 
[5] E. Rehber, "İlköğretim İkinci Kademe Öğrencilerinin Empatik Eğilim Düzeylerine Göre Çatışma Çözme Davranışlarının İncelenmesi," Yüksek Lisans tezi, Sosyal Bilimler Enstitüsü, Çukurova Üniversitesi, Adana, Türkiye, 2007.

[6] Ş. Aslan, "Bireyler Arası Çatışmayı Çözümleme Yöntemlerinin Algılanan Stres Düzeyiyle İlişkilerinin Araştırılması," KMU IIIBF Dergisi, c. 10, s. 15, ss. 304-323, 2008.

[7] V.M. Elgin ve N. Mamatoğlu, "Gezi Parkı Olayları: Namus Kültürü ve Çatışma Çözüm Tarzları Açısından Bir Değerlendirme,” Alternatif Politika Dergisi, c. 6, s. 1, ss. 3-31, 2014.

[8] E. Üngüren, "Örgütsel Çatışma Yönetimi Üzerine Konaklama İşletmelerinde Bir Araştırma," Uluslararası Sosyal Araştırmalar Dergisi, c. 1, s. 5, ss. 881-909, 2008.

[9] Anonim, Düzce Ticaret ve Sanayi Odası, Üye kayıtları listesi, 2013.

[10] Anonim, Bolu Ticaret ve Sanayi Odası, Üye kayıtları listesi, 2013a.

[11] Anonim, Bartın Ticaret ve Sanayi Odası, Üye kayıtları listesi, 2013b.

[12] S. Lemeshow, Jr. D.W. Hosmer, K. Janelle and S.K. Lwanga, "Adequacy of Sample Size in Health Studies, ” Published by World Healt Organization. Tiptree, Colchester, ISBN: 047192517 9, Courier International Ltd, 1990.

[13] S. Neiderauer, "Üniversite Üst Düzey Yöneticilerinin Kişilik Tipleri ve Örgütsel Çatışmayı Çözme Stratejileri," Doktora tezi, Eğitim Bilimleri Enstitüsü, Dokuz Eylül Üniversitesi, İzmir, Türkiye, 2006.

[14] H. Özgan, "İlköğretim Okulu Öğretmenlerinin Çatışma Yönetimi Stratejilerinin İncelenmesi (Gaziantep Örneği),” Doktora tezi, Sosyal Bilimler Enstitüsü, Gaziantep Üniversitesi, Gaziantep, Türkiye, 2006.

[15] A.U. Tarakcı, "Türk Özel Sektör Yöneticilerinin Çatışmaları Çözmede Kullandıkları Stiller ve Bu Stillerin Öz Yeterlilik Algılamasıyla İlişkisi," Yüksek Lisans tezi, Sosyal Bilimler Enstitüsü, Balıkesir Üniversitesi, Balıkesir, Türkiye, 2009.

[16] Y. İnandı, B. Tunç ve B. Gündüz, "Okul Yöneticilerinin Öz Yeterlik Algıları ile Çatışmayı Çözme Stratejileri Arasındaki İlişki," Kuram ve Uygulamada Eğitim Yönetimi, c. 1, s. 2, ss. 275-294, 2013.

[17] B. Ayan, "Örgütsel Çatışma ve Yönetimi: Kamu Örgütlerinde Bir Araştırma," Yüksek Lisans tezi, Sosyal Bilimler Enstitüsü, Gazi Üniversitesi, Ankara, Türkiye, 2018.

[18] K. Özdamar, Paket Programlar ile İstatistiksel Veri Analizi, 4. bask1, Ankara, Türkiye: Kaan Kitabevi, 2002.

[19] Ş. Kalaycı, SPSS Uygulamalı Çok Değişkenli İstatistik Teknikleri, 4. baskı, Ankara, Türkiye: Asil Basın Yayın Dağıtım, 2009.

[20] M.A. Rahim, "Toward A Theory of Managing Organizational Conflict," The International Journal of Conflict Management, c. 13, s. 3, ss. 206-235, 2002.

[21] S. Yürür, "Yöneticilerin Çatışma Yönetim Tarzları ve Kişilik Özellikleri Arasındaki İlişkinin Analizine Yönelik Bir Araştırma," C.Ü. İktisadi ve İdari Bilimler Dergisi, c. 10, s. 1, ss. 23-42, 2009. 
[22] U. Öztaş ve O. Akın, "Örgütsel Çatışma Yönetiminde Cinsiyet Farklılıkları: Antalya Serbest Bölgesinde Bir Araştırma," Organizasyon ve Yönetim Bilimleri Dergisi, c. 1, s. 1, ss. 9-24, 2009.

[23] H.İ. Arslantaş ve M. Özkan, "İlköğretim Okullarında Görev Yapan Öğretmenlerin Görüşlerine Göre Okul Müdürlerinin Çatışma Yönetimi Yaklaşımlarının İncelenmesi," Kastamonu Eğitim Dergisi, c. 20 , s. 2 , ss. $555-570,2012$.

[24] H. Yıldızoğlu ve B. Burgaz, "Okul Yöneticilerinin Beş Faktör Kişilik Özellikleriyle Çatışma Yönetimi Stili Tercihleri Arasındaki İlişki," Hacettepe Üniversitesi Eğitim Fakültesi Dergisi (H. U. Journal of Education), c. 29, s. 2, ss. 295-310, 2014.

[25] E. Sucuoğlu, "Devlet Lisesi Öğretmenlerinin Çatışma Nedenleri ve Çatışma Yönetimi Yaklaşımlarının Değerlendirilmesi," Hacettepe Üniversitesi Eğitim Fakültesi Dergisi, c. 30, s. 4, ss. $16-28,2015$.

[26] M. Konak ve M. Erdem, "Öğretmenlerin Görüşlerine Göre İlkokul Yöneticilerinin Etik Liderlik Davranışları ile Çatışma Yönetme Stratejileri Arasındaki İlişki," Kuram ve Uygulamada Ë̆itim Yönetimi, c. 21, s. 1, ss. 69-91, 2015.

[27] K. Arslan, "KOBİ'lerde Çatışma ve KOBİ Yöneticilerinin Çatışmanın Yönetiminde İzledikleri Stratejiler," Kocaeli Üniversitesi Sosyal Bilimler Dergisi, c. 32, ss. 35-62, 2016.

[28] E. İmamoğlu, "Örgütsel Çatışmanın Nedenleri ve Çalışanlar Üzerindeki Etkileri ve Kamu Kuruluşunda Bir Alan Araştırması," Yüksek Lisans tezi, Sosyal Bilimler Enstitüsü, Anadolu Üniversitesi, Eskişehir, Türkiye, 2014.

[29] U. Öztaş, "Örgütsel Çatışma ve Yönetiminde Cinsiyet Faktörünün Etkisi," Yüksek Lisans tezi, Sosyal Bilimler Enstitüsü, Akdeniz Üniversitesi, Antalya, Türkiye, 2015.

[30] S. Şahin ve F. Yüksel Şahin, "Okul Yöneticilerinin ve Öğretmenlerin Çatışma Yönetimi Stillerinin Sosyal Zekâ ve Bazı Kişisel Değişkenlere Göre İncelenmesi," Kalem Eğitim ve İnsan Bilimleri Dergisi, c. 7, s. 2, ss. 391-418, 2017.

[31] S. Polatc1 ve F. Sobacı, "Dönüşümcü ve Etkileşimci Liderlerin Çatışma Yönetim Strateji Tercihlerinin İncelemesi: Türkiye Örneği," Ömer Halisdemir Üniversitesi İktisadi ve İdari Bilimler Fakültesi Dergisi, c. 10, s. 3, ss. 27-40, 2017. 